УДК 321.013

DOI

\begin{tabular}{|c|}
\hline $\begin{array}{r}\text { М.Г.Тараненко } \\
\text { orcid.org/0000-0002-4283-5757 } \\
\text { кандидат історичних наук, } \\
\text { доцент кафедри публічного права } \\
\text { ій політехнічний інститут імені }\end{array}$ \\
\hline $\begin{array}{r}\text { М.М.Тараненко } \\
\text { orcid.org/0000-0002-1594-5598 } \\
\text { кандидат юридичних наук, } \\
\text { доцент кафедри публічного права }\end{array}$ \\
\hline
\end{tabular}

\title{
КОНСТИТУЦІЯ ПИЛИПА ОРЛИКА 1710 РОКУ ЯК ПЕРШОДЖЕРЕЛО РОЗВИТКУ КОНСТИТУЦІОНАЛІЗМУ В УКРАЇНІ
}

Постановка проблеми. Цього року наша країна відзначає 25-річний ювілей ухвалення Конституції України. У цьому контексті варто нагадати, що перший вітчизняний конституційний акт був ухвалений понад 300 років тому і увійшов в історію українського конституціоналізму як Конституція Пилипа Орлика 1710 р., яку слушно вважають однією з перших світових конституцій. Ї̈̈ творці заклали першооснови формування демократичної правової держави, а деякі положення Конституції 1710 р. залишаються актуальними і в умовах сьогодення.

Стан дослідження. Перші наукові дослідження, присвячені даній проблематиці, з'явилися за часів української революції 1917-1921 pp. I в наступний після неї період. Серед них варто виокремити працю М. Василенка, присвячену аналізу основних положень Конституції 1710 р., іï ролі в історії українського державотворення. В умовах незалежності України з'являються наукові розвідки О. Апанович, В. Замлинського, В. Ульяновського, О. Субтельного, Т. Чухліба й інших учених, у яких висвітлюються маловідомі сторінки життя П. Орлика, аналізуються основні положення його Конституції. Детальний політико-правовий аналіз і оцінку цього документа дають у своїх працях історики-правники О. Лукашевич, К. Манжул, О. Кресін, І. Бойко й інші.

Актуальність і мета дослідження. Зауважимо, що вказана наукова проблема має і нині чимало «білих плям», які, на жаль, залишаються без грунтовних і об'єктивних оцінок. У цьому зв'язку, на наш погляд, на більш глибоке осмислення дослідниками заслуговує проблема встановлення головних умов і причин розроблення Конституції 1710 р., аналізу її основних положень, значення цієї видатної політико-правової пам'ятки в розвитку українського державотворення. У цьому полягають актуальність і мета даної статті.
Виклад основного матеріалу. Після поразки шведського короля Карла XII та його союзника українського гетьмана I. Мазепи під Полтавою в червні 1709 р. нечисленні залишки шведського війська та найбільш послідовні прихильники I. Мазепи опинилися поза межами України, у місті Бендери, де тодішні володарі цих земель - турки дали згоду на їх притулок. Ситуація, що склалася в середовищі українських емігрантів, була досить напруженою. І. Мазепа після панічної втечі з України тяжко захворів і майже не вставав з ліжка. Козацька старшина, яка не бачила реальних перспектив свого повернення в Україну, була помітно знервована. Усього за кордоном опинилося 45 старшин, які вважали себе послідовними мазепинцями. До них також приєдналися приблизно 500 рядових козаків [13, с. 51-52]. Найчисленнішу групу серед українських емігрантів становили $3-4$ тисячі запорожців $[18$, с. 20$]$.

На відміну від інших втікачів, які перебували в жахливому моральному і матеріальному стані, I. Мазепа, заздалегідь передбачивши можливість найгіршого розвитку подій, зумів вивезти із собою майже все своє багатство. За словами очевидців, приміщення, де він розмістився, було завалено мішками із золотом і коштовностями.

Занадто напружену ситуацію в таборі українських емігрантів постійно ускладнювали своїми непередбачливими діями невдоволені запорожці. Вони вважали I. Мазепу головним винуватцем їхнього жалюгідного становища. Тому гетьману доводилося постійно заспокоювати їх щедрими обіцянками і подарунками $[13$, с. 53$]$.

Бажане порозуміння серед різних верств українських вигнанців відновилося лише після смерті I. Мазепи в ніч із 21 на 22 вересня 1709 р. 3 його кончиною відразу постало питання: чи залишив покійний гетьман відповідні рекомендації 
щодо кандидатури свого наступника, чи висловив конкретні розпорядження стосовно долі своï скарбів? Як з'ясувалося, зробити це він так i не встиг. Тому після смерті I. Мазепи перед українцями-емігрантами відразу постали три найбільш важливі і гострі питання:

- обрання нового гетьмана;

- визначення першочергових і перспективних напрямів його діяльності й української еміграції загалом;

- доля державного й особистого скарбу

I. Мазепи.

За таких обставин серед мазепинців передусім розгорнулася шалена боротьба за багатий гетьманський спадок, яка велася між небожем I. Мазепи А. Войнаровським і генеральною старшиною. Визначальним у цій гострій суперечці було питання, чи були скарби I. Мазепи його приватною власністю, чи надбанням Війська Запорозького.

Козацька старшина вирішила залучити до вирішення цієї складної проблеми Карла ХII. 22 жовтня 1709 р. вона надіслала шведському королеві меморандум, у якому висловлювалися сподівання щодо поновлення дружніх зв'язків України зі Швецією, які допоможуть скинути з України «московське ярмо». У ньому також висловлювалося настійливе прохання якомога швидше обрати нового гетьмана. Для цього козацька старшина прохала «визначити певну особу з королівського боку для вирішення цієї проблеми, оповісти Запорозькому війську про вільний вибір нового гетьмана й призначити час і місце вибору» [15,с. 431]. Автори меморандуму вважали, що вибори нового гетьмана можуть бути проведені лише після вирішення питання про скарби I. Мазепи. На думку старшини, якщо гетьманська скарбниця порожня, буде складно обрати нового гетьмана. Адже як новообраний гетьман виконуватиме свої повноваження і продовжуватиме боротьбу проти росіян, не маючи у своєму розпорядженні грошей. Звернувся до короля й А. Войнаровський, зауваживши, що він також має бажання боротися проти росіян, але не усвідомлює, чому цю боротьбу треба фінансувати із власних коштів його дядька [13, с. 53-54].

Створена Карлом XII комісія дійшла висновку, що I. Мазепі, як і більшості попередніх український гетьманів, було складно відрізняти особисту власність від власності Війська Запорозького. У цьому зв'язку варто висвітлити деякі аспекти дебатів про громадські та приватні інтереси, що виникли між козацькою старшиною й А. Войнаровським. Коли старшина стала звинувачувати I. Мазепу в зумисному об'єднанні своїх особистих коштів зі скарбницею Війська (на шкоду останній), то А. Войнаровський зазначив, що в цьому не було нічого нового. Адже так робили майже всі гетьмани, Б. Хмельницький також. Даючи відповідь на твердження старшини, що в інтересах «громадського добра» треба використати багатства I. Мазепи для подальшої боротьби проти Москви, А. Войнаровський цинічно заявив, що «громадські справи треба ставити вище від приватних тоді, коли вони не валяться до грунту, а лишають надію на недалеку поправу, та коли вони нищать цю надію, природніше видається рятувати особу, життя, здоров'я й усе, що з ним зв'язане» [13, с. 55].

Бурхливе обговорення фінансової проблеми яскраво засвідчило, наскільки глибокими свого часу були суперечності між I. Мазепою і старшиною. Критикуючи фінансову практику гетьмана, колишні однодумці I. Мазепи із прикрістю наводили приклади його самодержавних методів керівництва і відкрито стверджували, що «й москалі, й гетьман наложили ярмо на Україну». У свою чергу, відповідаючи старшині, що йому дивно чути, як «освободителя батьківщини проголошують її гнобителем», А. Войнаровський зазначив, що його дядько завжди відчував до неї не так огиду, як зневагу, нерідко картаючи її представників за «їхню невчену мову та брутальні манери». На його запитання, чому старшина не скаржилася цареві на зловживання I. Мазепи, вона відповіла, що не хотіла руйнувати державний лад Гетьманщини, похмуро додавши, що Петро I «не вірив би й янголові, якщо той доніс би про надужиття гетьмана» [13, с. 55].

У кінцевому підсумку справу про скарби I. Мазепи виграв А. Войнаровський. Як згодом з'ясувалося, він зумів підкупити свідків, пообіцявши їм частку отриманого їм багатства.

Після такого скандального вирішення фінансової проблеми вибори нового гетьмана не відбувалися цілих півроку. За цей період Петро I призначив наступним гетьманом України I. Скоропадського. Проте представники української еміграції вирішили не визнавати його. Вони ухвалили рішення чекати перемоги Карла XII над Петром I, свого повернення в Україну, а потім законних перевиборів козацького керманича. Проте час швидко спливав, а складна ситуація не змінювалася. Тому питання про вибори нового гетьмана було нарешті поставлене. На цю посаду після ганебної поведінки під час вирішення фінансового питання А. Войнаровського фактично розглядалося дві можливі кандидатури: прилуцький полковник Дмитро Горленко і генеральний писар Пилип Орлик. Перший не мав необхідної популярності і підтримки серед козаків. П. Орлик же мав заслужений авторитет, відзначався своїм розумом, широкими знаннями та дипломатичним досвідом. Саме його кандидатуру підтримував Карл XII.

Як 3'ясувалося, шведський король також мав власні мотиви і причини щодо необхідності обрання нового гетьмана. Адже вже в Бендерах 
принижений і пригнічений поразкою під Полтавою Карл XII мріяв про обов'язковий реванш і виношував амбітні плани нової війни проти російського царя. Своїм союзником у реалізації цих задумів він уважав насамперед Туреччину, але не виключав, що під вмілим керівництвом й українці змогли б стати дуже корисними в цій справі.

П. Орлик поки не отримав від шведського короля гарантії, що той не піде на мир із росіянами, доки «московське ярмо не буде знято з України й країна не повернеться до своїх давніх вольностей» [13, с. 57].

5 квітня 1710 р. під Бендерами на загальній козацькій раді П. Орлика одностайно було обрано гетьманом України в екзилі. Церемонія обрання гетьмана мала важливу особливість. Уперше він обирався на чужині і вперше в історії українського козацтва гетьман укладав зі своїми виборцями офіційну угоду, де були чітко прописані умови, за яких новий козацький очільник отримував гетьманську булаву. В українській історіографії цей правовий акт назвали «Бендерською конституцією», або Конституцією Пилипа Орлика 1710 р. Повна назва укладеної угоди в перекладі з латині звучить так: «Пакти й конституції законів та вольностей Війська Запорозького» між ясновельможним паном Пилипом Орликом, новообраним Гетьманом Війська Запорозького та між старшиною, полковниками, а також названим Військом Запорозьким, прийняті публічною ухвалою обох сторін і підтверджені на вільних виборах встановленою присягою названим ясновельможним гетьманом, року Божого 1710, квітня 5, при Бендерах [11, с. 25].

Головним автором і редактором Конституції був, безсумнівно, майбутній новообраний гетьман П. Орлик. Окрім цього, у її опрацюванні й остаточному ухваленні брали участь: небіж I. Мазепи А. Войнаровський, кошовий отаман Запорозької Січі К. Гордієнко, прилуцький полковник Д. Горленко, генеральний обозний I. Ломиковський, генеральний бунчужний Ф. Мирович, генеральний осавул Г. Гердик, генеральний писар I. Максимович, генеральний суддя К. Довгополий, а також інші старшини та представники рядового козацтва [6, с. 24]. Зазначимо, що над цим конституційним актом вони працювали із другої половини лютого до початку квітня 1710 р. Цікаво, що водночас представники українських емігрантів декілька разів таємно відвідували Лівобережжя України для консультацій з окремими представниками уряду новообраного там гетьмана I. Скоропадського [6, с. 24].

Варто зазначити, що за своєю формою Конституція Пилипа Орлика була схожа з угодами, які польська шляхта укладала зі своїми виборними королями. Вона складалася із преамбули та 16 статей, досить різних за своїм обсягом, змістом і значенням. У них чітко проглядалися політичні погляди й інтереси не лише мазепинських емігрантів, а й багатьох їхніх однодумців, які перебували на той час в Україні. Цей конституційний акт не був звичайною теоретичною розробкою чи спробою відірваних від тодішніх українських реалій ідеалістів видати бажане за дійсне. Адже на час розроблення Конституції вже йшла активна підготовка до нового військового походу проти російського царя. Тому вона фактично проголошувала, які саме реальні радикальні зміни будуть запроваджені в Гетьманщині після переможної війни проти Росії.

Конституція починається зі вступу-преамбули, де викладена коротка історія українського народу - «народу бойового, стародавнього, козацького», обгрунтовується становлення Української козацької держави, а також її відхід від Речі Посполитої. Але прийняття Б. Хмельницьким зверхності Москви призвело до спроб останньої знищити традиційні права та вольності козаків. Тому I. Мазепа спробував зарадити лихові, порвавши відносини з Москвою й уклавши союз зі шведами. Щоб завершити його справу, Військо Запорозьке обрало своїм гетьманом Пилипа Орлика. Наприкінці преамбули наголошується, що Конституції 1710 р. має дотримуватися як новообраний «вільним голосуванням» гетьман, так і його наступники на гетьманській посаді [16, с. 179-182].

Окремі дослідники «Бендерської конституції» зазначали, що її статті здаються зібраними без жодного логічного змісту і впорядкування. Однак детальне вивчення цього документа, на думку О. Субтельного, свідчить, що його 16 пунктів досить чітко розбиваються на чотири цілком логічно змістовні розділи [13, с. 61$]$.

I. Загальноукраїнські завдання (ст. ст. 1-3).

У ст. 1 наголошується, що православна віра, заради якої Б. Хмельницький свого часу прийняв московське заступництво, має бути у країні панівною релігією. ЖКодна інша віра, особливо іудаїзм, не допускатиметься. Прагнення українців розірвати стосунки з Москвою підкреслювалося конкретною пропозицією: щоб усунути московський вплив і піднести престиж Київського митрополита, варто знову перейти під зверхність Константинопольського патріарха, оскільки «звитяжний народ козацький був просвітлений у столиці апостольській Константинопольській» [11, с. 27]. Як бачимо, підпорядкування Київського митрополита Московському патріархові в 1680 р. досить боляче сприймалося українцями, насамперед духовенством, з яким П. Орлик підтримував давні добрі відносини.

Друга стаття обгрунтовувала становлення кордонів і забезпечення територіальної цілісності Української козацької держави, яка мала об’єднувати Правобережжя, Лівобережжя та 
Запорожжя. «Як кожна держава складається i стверджується непорушною цілістю кордонів, так і Мала Росія, вітчизна наша, щоб у своїх кордонах, стверджених пактами від Речі Посполитої і від Московської держави, була» [11, с. 27]. За прикладом Б. Хмельницького, кордоном із поляками проголошено річку Случ. Однак про чіткий кордон із Московщиною не говориться, бо це питання залишалося досить проблематичним через Слобожанщину, яка була заселена переважно українцями, але перебувала під владою Росії. У ст. 3 гетьман уповноважувався укласти союз із Кримським ханством, «оскільки закони близького сусідства нерозривно в'яжуть і тісно поєднують долю козацького народу із Кримською державою» [16, с. 185]. Напевно, творцям Конституції було досить складно знайти за кордоном надійних союзників у боротьбі проти Москви. Тому вони й змушені були забути про трагічні наслідки для України всіх попередніх українсько-кримсько-татарських союзів, починаючи від Б. Хмельницького і продовжуючи його послідовниками. На жаль, П. Орлик жодної практичної користі від цього союзу зрештою так і не отримав, а, як і всі його попередники, у вирішальний момент боротьби за відродження української державності вкотре був підступно зраджений кримськими татарами.
II. Проблеми
запорозького
козацтва

(ст. ст. 4-5).

Зважаючи на те, що запорожці становили в Бендерах більшість українських емігрантів, їхні інтереси були досить широко представлені в Конституції 1710 р. Зокрема, у ст. 4 детально йдеться про їхню головну проблему - російську військову присутність у пониззі Дніпра, де росіяни побудували цілу низку фортифікаційних споруд для захисту від постійних нападів татар. Ці військові укріплення давали змогу росіянам постійно втручатися у внутрішні справи запорожців. Тому вони вимагали: якщо під час майбутнього військового походу «Запорозьке військо не очистить тих грунтів своїх і Дніпра од московського насильства», гетьман, у разі укладання переможної мирної угоди із царем, повинен переконати шведського короля домогтися виводу російських військ із цих земель [11, с. 29]. У ст. 5 під контроль січовиків вимагалося передати місто Трахтемирів, що віддавна слугувало їм за шпиталь і місце для перебудування старих і недужих козаків. Сповнені рішучості тримати пониззя Дніпра у своїх руках, запорожці прагнули отримати також низку ключових міст усього регіону та гарантію гетьмана допомагати їм не допускати стороннього втручання в їхні внутрішні справи [16, с. 185-186]. За словами Д. Яворницького, у Конституції 1710 p. запорожці чітко визначили всі ті вимоги, які вони висували в різні часи всім гетьманам, починаючи з I. Виговського, і всім царям із часів царя
Олексія Михайловича [18, с. 347]. На думку О. Субтельного, ці вимоги надавали січовикам широку автономію, яку інші гетьмани - попередники П. Орлика не визнавали, постійно боролися проти автономного статусу Запорозької Січі [13, с. 63].

III. Організація державного правління Гетьманщини (ст. ст. 6-10).

Провідна частина Конституції П. Орлика починається із цілком риторичного запитання: якщо в автократичних державах постійно проводяться наради і навіть самодержці нерідко прислухаються до порад своїх міністрів, то чому в такого вільного народу, як козаки, обрані ними гетьмани не обговорюють посталі перед Гетьманщиною проблеми з козацькою верхівкою? До того ж такі демократичні традиції мали місце ще в недалекому минулому. Як зазначають творці Конституції, ця проблема виникла лише тоді, коли гетьмани потрапили під владу самодержавних правителів, саме від них узаконили самовладно таке право i в Україні: «Так хочу, так повеліваю!». Авторами цих статей були представники генеральної старшини, яка вже тривалий час обурювалася, що усунута гетьманами від ухвалення доленосних рішень в Україні. Після смерті I. Мазепи генеральна старшина дістала реальний шанс знову повернути свій втрачений колись політичний вплив. Щоб тримати майбутніх гетьманів під своїм контролем, вона бажала запровадження в Гетьманщині дорадчого права. Зокрема, від гетьманів в Конституції вимагалося, щоб вони постійно радилися з генеральною старшиною та полковниками щодо всіх важливих питань, особливо тих, що стосувалися міждержавних відносин. Окрім цього, кожен полк мав обирати «генеральних радників із людей розважливих і заслужених». Передбачалося, що вони братимуть участь у дорадчих вібраннях при гетьмані, які проводитимуться тричі на рік [16, с. 186-187]. У політичному сенсі ст. 6 була найважливішою в Конституції, оскільки давала дозвіл старшині тримати під контролем діяльність гетьманів, подібно до того, як польська шляхта контролювала діяльність обраних нею королів. Зрозуміло, що в цьому положенні була певна логіка, адже козацька старшина після смерті I. Мазепи не боялася фактично відкрито виступила проти його самодержавних методів гетьманування, керуючись аналогічними мотивами, з яких сам гетьман нещодавно піддавав критиці жорстокий абсолютизм царя Петра I, запроваджений у Московії.

Варто зауважити, що на запровадженні дорадчого права владні повноваження старшини згідно з Конституцією не обмежувалися. Вона також вимагала заборонити гетьманам карати тих, хто ображав їхню честь і гідність. Ці справи, за пропозицією старшини, мав розглядати Генеральний суд (ст. 7) [16, с. 188]. 
У всіх важливих справах послідовно простежується прагнення старшини чітко розмежувати громадський і приватний сектори. Водночас гетьман повинен був залучати до цих справ відповідних чиновників Війська, а не своїх особистих слуг (ст. 8). Після гострої суперечки за Мазепині скарби старшина особливо наполягала на розмежуванні прибутків Війська і гетьмана. Із цією метою у ст. 9 Конституції пропонувалося запровадити посаду генерального підскарбія, на яку міг бути обраним лише «чоловік значний і заслужений, маєтний і порядний» [11, с. 32]. Гетьман віднині позбавлявся доступу до державних коштів; він мав жити тільки коштом власних маєтностей, спеціально виділених для його потреб. Свої прибутки гетьман мав отримувати від індукти з Гадяцького полку, Шепаківської сотні та Почепівських і Оболонських «маєтків». Окрім цього, кожен полк також мав обирати двох підскарбіїв з аналогічними обов'язками і повноваженнями. Отже, у Гетьманщині і в політичному, і в економічному сенсі вказані статті помітно обмежували владні повноваження гетьмана і значно посилювали владні можливості генеральної старшини. Як цілком слушно зазначають щодо цього В. Смолій та В. Степанков, Конституція П. Орлика була спрямована проти встановлення в Україні монархічної форми правління в особі спадкоємного Гетьманату і передбачала утвердження ідеї олігархічної республіки [12, с. 218].

IV. Заходи проти соціально-економічних зловживань (ст. ст. 10-16).

Заключна частина Конституції присвячена усуненню зловживань козацької верхівки в Гетьманщині. Дивно, що, незважаючи на величезний вплив старшини в Бендерах, до неї увійшли статті, які безпосередньо зачіпали інтереси козацької еліти. Цілком можливо, що ці, наповнені популістичними гаслами, статті було включено до Конституції лише із пропагандистською метою, щоб привернути на свій бік простий люд. Не виключено, що інтереси нижчих верств обстоювали запорожці, більшість яких вийшли саме із цієї категорії населення України. Проте це не пояснює, чому в зазначених статтях порушено проблеми неприхованої корупції посадових осіб і безрадісного становища українських міст. Цілком можливо, що ці статті відбивали бажання їхніх авторів виправити найбільш разючі та болісні вади Гетьманщини навіть за рахунок власних інтересів. Не виключено, що заключна частина Конституції П. Орлика є конкретною відповіддю їі творців на відверто антинародну соціальну політику I. Мазепи, яка, як відомо, стала однією з головних причин провалу його антиросійських визвольних змагань. На наш погляд, цілком слушною в цьому сенсі була оцінка Конституції П. Орлика українським істориком О. Оглоблиним, який назвав її «другою поразкою гетьмана Мазепи після Полтавської катастрофи» [9, с. 38].

Повертаючись до змісту заключної частини Конституції, зазначимо, що ст. 10 застерігає старшину, щоб вона не використовувала свого становища для визиску козаків, селян і ремісників. $\mathrm{У}$ ній заборонялася практика купівлі керівних посад, оскільки «всілякі утиски та здирства бідним людям походять здебільшого від владолюбних накупів» . Для припинення цієї корупційної практики гетьман зобов' язувався ретельно стежити за тим, щоб усі посади, насамперед полковницькі, були виборними [11, с. 32-33].

Особливу турботу про нижчі верстви населення України висловлено у ст. ст. 11, 12 і 14. Відповідно до них родини козаків, які перебували у військовому поході, вдови й сироти звільнялися від сплати податків та виконання інших повинностей. $\mathrm{y}$ цих статтях обмежувався обтяжливий для селян обов'язок забезпечувати перевезення військових чиновників, передбачалося запровадження необхідних заходів, які полегшували б податковий тягар для найбідніших селян. 3 огляду на те, що в Україні, як і в усій Східній Європі, стосунки місцевої знаті з містами були вкрай напружені, особливо вражає ст. 13, у якій ідеться про жахливе зубожіння міст і пропонується, щоб «столичне місто Київ та інші українські городи» і надалі зберегли свої права та привілеї за магдебурзьким правом. У двох останніх статтях Конституції було передбачено конкретні заходи щодо полегшення тяжкого становища бідноти в Україні. У ст. 15, зокрема, передбачено, що податки із селян, які власним коштом утримували гетьманські компанійські та сердюцькі полки, мають бути скасовані, а остання стаття зобов'язує гетьмана ретельно стежити, щоб ринкові комісари не збирали 3 ярмаркових торговців такі високі податки, «через які неможливо взагалі убогій людині вільно 3'явитись на ярмарок» [11, с. 35].

До основного тексту Конституції додавалася присяга новообраного гетьмана, який зобов'язувався дотримуватися та впроваджувати в життя положення угоди в «усіх розділах, уривках, поняттях і клаузулах», бути відданим «нашій Вітчизні та дбати про її суспільне благо і соборність» [16, с. 193].

Як бачимо, більшість статей Конституції П. Орлика були спрямовані проти проявів абсолютизму в Гетьманщині та встановлення демократичної республіканської форми правління, що базувалася б на визнанні непорушності трьох чинників правового суспільства, як-от єдність і взаємодія законодавчої (виборна Генеральна Рада, що мала б скликатися тричі на рік), виконавчої (гетьман, обмежений законом у своїх діях, генеральна старшина та виборні представники від кожного полку) і судової влади (Генеральний Суд), підзвіт- 
ної та контрольованої. Такими, на наш погляд, визначалися принципи побудови Української держави. Водночас Конституція проголошувала значне розширення прав різних категорій населення тогочасної України: козацької старшини, рядових козаків, запорожців, міщан, селян, найбідніших простолюдинів. Ці права, як відомо, після смерті Б. Хмельницького постійно порушувалися або взагалі ігнорувалися за часів його наступників, особливо в умовах гетьманування I. Мазепи.

У результаті проведеного аналізу основних положень цього першого вітчизняного конституційного акта М. Грушевський зазначав: «Хоч ці постанови не були здійснені, бо взяти Україну у свої руки сим людям не удалося ніколи, - але вони цікаві, як вираз поглядів і бажань сих людей, що зв'язали свою долю з визволенням України. В постановах сих багато нового, що могло бути важним кроком наперед». На його думку, Конституція Пилипа Орлика насамперед була спрямована проти гетьманської «самодержавної влади», що узаконила своїм «самовластієм право: так хочу, так повеліваю» і проголошувала замітні початки чисто парламентського устрою» [3, с. 383-384].

Один із перших дослідників Конституції 1810 p. відомий український історик права М. Василенко називав цей документ як «своєрідну українську Конституцію, що свідчить про напрямок політичної думки української еміграції того часу. Ідеї, закладені в основу угоди Орлика, поділяли не лише емігранти, а й найбільш свідома частина старшини, яка не пристала до Мазепи». За його словами, це була конкретна і відкрита конституційна відповідь старшини на гетьманування I. Мазепи, його попередників, відкрита незгода і засудження їхьої політики в Гетьманщині. Договір був розрахований на те, що він діятиме в Україні як правовий акт після повернення до неї емігрантів. Отже, він може вважатися конституційним актом, де обгрунтовувався новий державний лад Гетьманщини [2, с. 153-171].

Даючи оцінку Конституції П. Орлика, український історик О. Оглоблин наголошував, що це був колективний вияв української політичної думки, підсумок дискусій 1709-1710 рр. трьох українських політичних сил - гетьмана, старшини, запорожців. За його словами, Конституція декларувала станову виборну гетьманську монархію парламентського типу [15, с. 436-437].

На відміну від нього, сучасний український правник О. Кресін переконаний, що Конституція П. Орлика 1710 р. стала першим українським конституційним проєктом. Вона встановила форму правління, яку можна визначити як парламентсько-президентську республіку. Уперше в українській історії було створено правові основи представницького правління та парламентаризму. «Пакти» розподілили владні повноваження, що до цього часу належали цареві, між органами влади Війська Запорозького та створили правові передумови для подолання розірваності українського політичного і правового процесів [7, с. 201].

На думку В. Замлинського, «Бендерська конституція» своїми ідеями, демократичними засадами, змістом і державницькою спрямованістю була попереду суспільної думки тогочасної Європи. Навіть французькі просвітителі ще тільки наближалися до розробки тих суспільних ідей, що були закладені в Конституції П. Орлика, яка стала реальною моделлю вільної, незалежної держави, заснованої на природному праві, що базувалася на незнаних досі демократичних засадах суспільного життя [5, с. 347].

Д. Донцов зазначав, що «це була перша - у сучасному розумінні цього слова - конституція України, яка проголошувала проєкт нового державного ладу, що був вироблений за 79 років перед Великою французькою революцією» [4, с. 17].

Сучасний український політолог С. Телешун наголошує, що поява першої у світі конституції саме в Україні є фактом визначним: адже першу конституцію було написано у країні, яка тільки розпочала боротися за свою державність. За його словами, подальша світова історія переконливо засвідчила, що конституційне закріплення правових норм відбувається саме під час соціальних катаклізмів, під час пошуку народами шляхів свого державотворення [14, с. 19].

За оцінкою О. Оглоблина, Конституція, у якій гармонійно поєднано інтереси гетьманату, старшини, як провідної верстви України, та Запоріжжя, як її військової сили, була водночас маніфестом державної волі української нації перед цілим суспільним світом, «віковічним пам'ятником української державно-політичної думки» [17, с. 133]. У цьому з ним згоден Т. Чухліб, який уважає, що положення договору 1710 р. узагальнювали накопичений протягом попередніх століть державотворчий потенціал українського народу і стали ідеологічним підгрунтям для подальших його виступів за незалежність. «Пакти та конституції <...>» заклали основу розвитку вітчизняного конституціоналізму нової та новітньої доби і стали визначною історичною пам' яткою національної та європейської політичної думки XVIII ст. [6, с. 27].

Досить оригінальну оцінку Конституції Пилипа Орлика висловила О. Апанович, яка зазначила, що вона є однією з найвидатніших історичних державно-політичних пам'яток і мусить зайняти належне їй місце в європейській історіографії. За її словами, даний конституційний акт і нині зберігає актуальність для депутатського корпусу сучасного парламенту незалежної самостійної України [1, с. 220].

Водночас варто зауважити, що не всі дослідники «Бендерської конституції» одностайно 
в позитивному контексті оцінюють цей юридичний опус українських політичних емігрантів. Зокрема, О. Субтельний уважає, що вона, з одного боку, «сповнена духу просвітництва й добрих намірів». Цей документ визнає права старшини, простолюду, запорожців і міст. Він засуджує абсолютистські прояви в діяльності гетьмана, стверджує принцип виборності, засуджує корупцію і проводить межу між державною та приватною сферами. 3 іншого боку, О. Субтельний підкреслює, що автори документа керувалися речами, якими на той час не володіли. Зокрема, «конституція» різко обмежувала прерогативи гетьмана, але гетьман у вигнанні багатьма з них скористатися не міг; у деяких статтях старшина погоджувалася утримуватися від корупції та визиску селян і козаків, але на такі вчинки їй не важко було погодитися, перебуваючи на чужині, не володіючи там нічим; запорожцям обіцяно землі в пониззі Дніпра, які належали Росії. Отже, хоча наміри мазепинців гідні похвали, як зазначає О. Субтельний, не варто робити скоро поспішні висновки щодо того, наскільки реальними були пропоновані ними заходи $[13$, c. 65].

Не у великому захваті від Конституції П. Орлика був і український історик I. Крип'якевич. Позитивно оцінюючи її роль у справі реформування державного устрою Гетьманщини, він звертав увагу на її егоїстично класовий чи груповий характер. На його думку, у Конституції йшлося про охорону і збільшення соціальних та політичних «вольностей» лише окремих груп, а не про розбудову держави. 3 питань загального значення авторами порушене тільки одне - закріплення західного кордону, і то по р. Случ. За його словами, «творці Конституції - старшина і запорожці - не виявили широкого політичного світогляду» [8, с. 237-238].

Висновки. У підсумку зазначимо, що Конституція Пилипа Орлика 1710 р., незважаючи на отриману у вітчизняній історії персональну назву, насправді не була особистим витвором гетьмана України в екзилі, а колективною вимогою представників першої української політичної еміграції: частини козацької старшини, представників запорожців та рядового козацтва, які за часів гетьманування I. Мазепи були позбавлені своїх прав, привілеїв і свобод та були усунуті ним від участі в керівництві державою. Саме цими вимогами вони намагалися повернути в Україні колишні демократичні традиції, започатковані Б. Хмельницьким. Важливо, що основні положення першого українського конституційного акта, на відміну від інших тогочасних європейських держав, де панував абсолютизм, заклали міцні основи представницького врядування та парламентаризму, створювали широкі можливості для запровадження в Україні республіканської форми правління.

\section{Jimepamypa}

1. Апанович О. Гетьмани України і кошові отамани Запорозької Січі. Київ : Либідь, 1993. 288 с.

2. Василенко Н. Конституция Пилипа Орлика. Ученые записки Института истории Российской ассоциации научно-исследовательских институтов общественных наук. Москва, 1929. Т. 3. С. 153-171.

3. Грушевський М. Шведсько-український союз 1708 p. Великий українець : Матеріали 3 життя та діяльності М.С. Грушевського. Київ : Веселка, 1992. 551 с.

4. Донцов Д. Історія розвитку української державної ідеї. Київ : Товариство «Знання» України, $1991.48 \mathrm{c}$.

5. Замлинський В. Пилип Орлик. Історія України в особах: IX-XVIII cm. / В. Замлинський (кер. авт. кол.) та ін. Київ : Україна, 1993. 396 с.

6. Енциклопедія історії України: у 10-и т. Київ : Наукова думка, 2011. Т. 8.520 с.

7. Кресін О. «Пакти й конституції законів i вольностей Запорозького Війська <...> 1710 p. Украӥнський історичний журнал. 2005. № 2. C. 192-203.

8. Крип'якевич I. Історія України. Львів : Світ, $1992.556 \mathrm{c}$.

9. Крупницький Б. Гетьман Пилипа Орлик (1672-1742). Його життя й доля. Мюнхен : Дніпрова хвиля, 1956.

10. Оглоблин О. Гетьман Іван Мазепа i Москва. Київ : Рада, 1994. 173 с.

11. Слюсаренко А., Томенко М. Історія української конституції. Київ : Товариство «Знання» України, 1993. 192 с.

12. Смолій В., Степанков В. Українська державна ідея XVII-XVIII ст. : проблеми формування, еволюції, реалізації. Київ : Альтернативи, 1997. 367 с.

13. Субтельний О. Мазепинці. Український сепаратизм на початку XVIII ст. Пер. 3 англ. В. Кулика. Київ : Либідь, 1994. 240 с.

14. Телешун С. Державний устрій України: проблеми політики, теорії i практики. Івано-Франківськ : Лілея-НВ, 2000. 344 с.

15. Ульяновський В. Пилип Орлик. Володарі гетьланської булави. Київ : Варта, 1994.560 с.

16. Хрестоматія 3 історії держави i права України : навчальний посібник / упорядн. : А. Чайковський (кер.) та ін. Київ : ЮрінкомІнтер, 2003. $656 \mathrm{c}$.

17. Шевчук В., Тараненко М. Історія української державності : Курс лекцій. Київ : Либідь, 1999. 480 с.

18. Яворницький Д. Історія запорозьких козаків : у 3-х т. Київ : Наукова думка, 1990-1991. Т. 3. $1991.557 \mathrm{c}$.

\section{Анотація}

Тараненко М. Г., Тараненко М. М. Конституція Пилипа Орлика 1710 року як першоджерело розвитку конституціоналізму в Україні. - Стаття.

У статті проаналізовано основні причини розробки першого вітчизняного конституційного акта - Конституції Пилипа Орлика 1710 року (Договори і Постановлення прав і вольностей Війська Запорозького), показано сутність цього видатного політико-правового документа, його значення в боротьбі українського народу за власну національну державність. Заслуговує на увагу детальне висвітлення реальних умов, у яких опинилася українська козацька еміграція після поразки короля Карла XII в Полтавській битві 1709 року. 
Після смерті гетьмана I. Мазепи козацьку старшину турбувало вирішення значного кола наболілих питань, що й стало основною причиною розроблення суспільного договору між нею та новобраним гетьманом. У проведеному дослідженні доведено, що Конституція 1710 року не була персональним витвором гетьмана в екзилі П. Орлика, а колективною думкою представників першої української політичної еміграції: козацької старшини, запорожців і представників рядового козацтва, які виступали проти антидемократичної самодержавної форми правління в Україні гетьмана I. Мазепи. Особлива увага приділялася усуненню економічних та корупційних зловживань гетьмана та козацької еліти як одній із найбільш гострих проблем, що потребувала негайного вирішення. У статті детально аналізуються преамбула й усі 16 статей Конституції, які за своїм змістом можна об'єднати в 4 окремі розділи: загальноукраїнські завдання, проблеми запорозького козацтва, організація державного правління Гетьманщини та заходи проти соціально-економічних зловживань у Гетьманщині. У дослідженні дається оцінка, підкреслюється значення Конституції 1710 року в розвитку політико-правової думки України XVIII століття і подальшому будівництві Української козацької республіки. Важливо, що основні положення першого українського конституційного акта, на відміну від інших тогочасних європейських держав, де панував абсолютизм, заклали міцні основи представницького врядування та парламентаризму, створювали широкі можливості для запровадження в Україні республіканської форми правління.

Ключові слова: Конституція, Пилип Орлик, гетьман-емігрант, козацька старшина, генеральна рада, генеральний суд.

\section{Summary}

Taranenko M. G., Taranenko M.M. The Constitution of Pylyp Orlyk of 1710 as the primary source of the development of constitutionalism in Ukraine. - Article.
The article analyzes the main reasons for the development of the first domestic constitutional act - the Constitution of Pylyp Orlyk in 1710 (Treaties and Resolutions of the Rights and Freedoms of the Zaporozhian Army) and shows the essence of this outstanding political and legal document and its importance in the Ukrainian people's struggle for national statehood. It is worth noting the detailed coverage of the real conditions in which the Ukrainian Cossack emigration found itself after the defeat of King Charles XII in the Battle of Poltava in 1709. After the death of Hetman I. Mazepa, the Cossack officer was concerned about the solution of a wide range of pressing issues, which became the main reason for the development of a social agreement between her and the newly elected hetman. That is why the study proved that the Constitution of 1710 was not a personal creation of the hetman in the exile of P. Orlyk, but the collective opinion of the first Ukrainian political emigrants: Cossack officers, Cossacks and ordinary Cossacks who opposed the anti-democratic autocratic rule in Ukraine. Hetman I. Mazepa. Particular attention was paid to eliminating the economic and corruption abuses of the hetman and the Cossack elite, as one of the most acute problems that needed to be addressed immediately. The article analyzes in detail the preamble and all 16 articles of the Constitution, which in their content can be combined into 4 separate sections: all-Ukrainian tasks, the problems of the Zaporozhian Cossacks, the organization of the Hetmanate and measures against socio-economic abuse in the Hetmanate. The study assesses and emphasizes the importance of the Constitution of 1710 in the development of political and legal thought of Ukraine in the 18'th century and the subsequent construction of the Ukrainian Cossack Republic. Importantly, the basic provisions of the first Ukrainian constitutional act, in contrast to other European states of the time, where absolutism prevailed, laid a solid foundation for representative government and parliamentarism 1 and created ample opportunities for the introduction of a republican form of government in Ukraine.

Key words: Constitution, Philip Orlyk, emigrant hetman, Cossack sergeant, general council, general court. 